\title{
РУССКИЕ КОНСЕРВАТОРЫ ВО ВТОРОЙ ПОЛОВИНЕ 1880-Х ГГ:. ВНЕШНЕПОЛИТИЧЕСКИЙ АСПЕКТ ${ }^{1}$
}

\section{RUSSIAN CONSERVATORS IN THE SECOND HALF OF THE 1880S: FOREIGN POLITICAL ASPECT}

\section{A. Kotov}

Summary: The article is devoted to the crisis that Russian conservative nationalists faced in the second half of the 1880s. - contrary to their own hopes connected with the coming to power of the «nationalist tsar» Alexander III. Part of the reason for the crisis was the death of three relatively independent intellectual leaders of this trend: I.S. Aksakova, M.N. Katkov and N.P. Gilyarov-Platonov. However, the reaction of Alexander III to the "foreign policy» activity that was carried out in 18861887 also played a role. M.N. Katkov and his associates, including General E.V. Bogdanovich. This activity, aimed at Russian-French rapprochement, also had internal political and ideological aspects.

Keywords: Katkov, Bogdanovich, Alexander III, nationalism, conservatism, salon, propaganda, journalism.
Котов Александр Эдуардович

Д.и.н., nрофессор, Институт истории Санкт-Петербургского государственного университета a.kotov@spbu.ru

Аннотация: Статья посвящена кризису, с которым русские консервативные националисты столкнулись во второй половине 1880-х гг. - вопреки собственным надеждам, связанным с приходом к власти «царя-националиста» Александра III. Отчасти причиной кризиса был уход из жизни трех относительно независимых интеллектуальных лидеров этого направления: И.С. Аксакова, М.Н. Каткова и Н.П. Гилярова-Платонова. Однако сыграла свою роль и реакция Александра III на ту «внешнеполитическую» деятельность, которую осуществляли в 1886-1887 гг. М.Н. Катков и его сподвижники, в том числе генерал Е.В. Богданович. Эта деятельность, направленная на русско-французское сближение, имела также внутриполитический и идеологический аспекты.

Ключевые слова: Катков, Богданович, Александр III, национализм, консерватизм, салон, пропаганда, публицистика, журналистика.
B 1860-е - 1870-е гг. русские консервативные националисты (славянофилы и М.Н. Катков) одержали решительную победу в идеологической борьбе как с «освободительным» движением, так и с сословным консерватизмом. Однако после Берлинского конгресса и последовавшей за ним утраты русского влияния на Балканах они сами оказываются в состоянии кризиса отчасти компенсированного надеждами, связанными с приходом к власти «царя-националиста» Александра III и тем влиянием, которое получили при нём М.Н. Катков и близкий к славянофильским кругам К.П. Победоносцев. Во второй половине 1880-х гг. этот идейный лагерь ждали новые потрясения, фактически положившие ему конец как самостоятельному общественному движению, а во многом предопределившие и крах будущего черносотенства. Новый кризис был связан, в том числе, и с уходом из жизни сразу трех своих относительно независимых интеллектуальных лидеров: И.С. Аксакова, М.Н. Каткова и Н.П. Гилярова-Платонова. Оставалось, разумеется, их окружение: «птенцы гнезда Каткова» и разного рода эпигоны типа С.Ф. Шарапова. Но это были люди уже совершенно иного масштаба: как отмечал взыскательный читатель, «померли "господа" (Катков и Аксаков), лакеи теперь, подлецы, дерутся ...» [8, с. 504].
Впрочем, Аксаков и Гиляров к концу своей деятельности уже воспринимались как реликты старого славянофильства. В противоположность им Катков считался и был одним из идейных руководителей политики правительства - но именно в этом качестве вызывал всё большее раздражение при дворе, а нередко и у самого государя. Попытки объявить Каткова (позиционировавшего себя как лидера патриотической общественности и защитника самодержавия) изменником или причастным к «измене» неоднократно предпринимались враждебными ему придворными кругами [21, с. 44]. Другим недоброжелателем Каткова и Победоносцева - одновременно идейным и личным - был государственный контролер Т.И. Филиппов, в письмах к своему протеже К.Н. Леонтьеву писавший о «союзе змия с опричником» [22, с. 225]. И, наконец, ненавидели Каткова в министерстве иностранных дел - чей неопределенный внешнеполитический курс был со времен Берлинского конгресса одним из главных объектов критики националистов. Всё это во многом и предопределило исход событий 18871888 гг. - которые, в свою очередь, сыграли важную роль в дальнейшей истории русского консерватизма. Эти события так или иначе затрагивались почти во всех работах, посвященных истории русско-французского движения, наиболее же подробно их разбирает в своих

Исследование выполнено при финансовой поддержке РФФИ в рамках научного проекта № 20-09-00005. 
недавних работах И. В. Лукоянов $[9,10]$. Не подвергая сомнению ценности предыдущих исследований, обратимся к внутриполитическому и, прежде всего, идеологическому аспекту этой истории.

Несмотря на то, что М.Н. Катков и его сподвижники выступали как пропагандисты эмансипации внешней политики от любых идеологических догм - монархического легитимизма, славянской взаимности и т.п., идея русско-французского сближения диктовалась не только соображениями «реализма» и «национального эгоизма». Как известно, Михаил Никифорович не был чистым практиком: его мышление и публицистика всегда отличались, по удачной формулировке А.Д. Галахова, «предпочтением умозрения эмпиризму и синтетическим способом изложения - от общих основ к частным выводом» [2, с. 98]. Союз с Францией также был закономерным продолжением катковской идеологии бюрократического национализма [7].

Еще в 1860-е годы Катков противопоставлял централизованную Францию, которая «может гордиться своей однородностью», многонациональной «химере» таких «имперских» идеологов, как Д.К. Шедо-Ферроти. Эта французская «однородность» стала возможной благодаря «неизменному характеру [...] правительства, которое сознавало себя головою и рукою единственно только французского народа, которое жило, двигалось, существовало единственно только в элементе французской национальности и которое во всей Франции признавало единственно только французскую народность» [12]. Не без зависти отмечал Катков, как «немецкие народонаселения, входя в государственный состав Франции, тем самым становились французами, и правительство Франции ничего другого не делало, как только признало этот факт во всей его истине и силе. К своим новым подданным оно отнеслось как к французам, и его новые подданные поспешили сравняться с французами. Французское правительство не имело надобности притеснять или насиловать их: оно только не ставило их в исключительные отношения к себе, и они сами собою стали французами. Во Франции сменялись всевозможные формы правления; Франция была и абсолютной монархией, и республикой, и военного диктатурой под именем империи, и конституционною монархией с династией, навязанною иностранным вмешательством, и конституционною монархией с династией, вышедшею из революции, и снова стала военного диктатурой; в течение этого короткого времени она пережила много переворотов, видела много торжеств и падений; но никогда, ни в каком случае, ни в каком положении, ни при какой перемене французское правительство, в чьих бы руках оно ни находилось, не переставало быть французским; как бы оно ни действовало в других отношениях, оно всегда действовало как правительство французское, и никогда не было ни бретонским, ни эльзасским и т.п., и не было также отвле- ченным, не имеющим никакой национальности принципом власти. Оно считало бы для себя бесславием, если бы в том или другом положении оно могло показаться не французским [...] Эта неизменная национальность французского правительства, в чьих бы руках оно ни находилось, спасала Францию от всех бед; оно сообщило французской нации ее несокрушимость» [12].

«Безнародным» крайностям аристократии и революции Катков и позднее противопоставлял национальные силы, победившие на выборах в Национальное собрание 1871 г. - когда своё слово смогла, наконец, сказать мелкобуржуазная французская провинция. Олицетворением этой Франции был подавлявший парижскую коммуну А. Тьер, который всегда «прежде всего, заботился о самостоятельной национальной политике Франции, и вся его политическая программа резюмируется его знаменитым возгласом в 1867 г.: “Давайте будем французами!"» [14]. Именно эту национальную Францию русский публицист уверял в том, что Россия не «желает воспользоваться бедствиями Франции для завоевательных целей или расширения своего влияния на Востоке. Германия гораздо более, чем Франция, заинтересована тем, чтобы Россия была отрезана от Востока, и Россия не может не знать этого. Отмена статьи Парижского трактата касательно Черного моря нейдет ни в какой расчет с фактом объединения Германии и фактом ее завоеваний» [15].

Во второй половине 1880-х сближение с Францией всё более становилось реальностью. В 1886 г. «Московские ведомости» подчеркивают происходящие во Франции перемены: «Заметно стремление правительства сколь можно более усилить государственную власть [...]. Профессия анархистов во Франции становится все менее привлекательною [...]. Можно с уверенностью сказать, что ни в одном государстве с монархическим образом правления с таким усердием никогда не разыскивались и не преследовались так называемые подозрительные лица, с каким в республиканской Франции [...]. Не менее ощутительно изменились отношения Франции к России. Газеты всех направлений теперь сходятся в сочувствии к нам» [16]. В марте 1887 г. газета подвела итог: «Еще недавно господствовала партийная, даже просто личная политика. Эту политику, надо отдать справедливость, изменил кабинет г. Фрейсине. На первый план выступила политика национальная, а правительство поставило себе задачей не только удержаться у власти, но и соблюсти честь Франции» [18].

Более откровенно мог высказываться Катков в своих записках к Александру III - которого «московский громовержец» почитал единственным достойным своим читателем. В них Михаил Никифорович подверг традиционной критике «министерство иностранных дел в России», всегда презиравшее «национальную политику»: «Наша 
дипломатия, следуя торным путям, на которых она служит более проводником чужой политики, нежели органом политики своей страны, старается очистить себя во мнении своих иностранных союзников, ссылаясь на замешательство, которое будто бы вносится в дела проявлениями личного усмотрения вашего величества. То, что поднимало дух в России и смущало ее врагов, что было ярким светом, мгновенно озарившим пути нашей политики, то, по толкованию дипломатов, было пертурбацией правильного течения дел, было их порчею и вело к неудачам, причем не договаривается, что причиною порчи и неудач было, напротив, двусмысленное отношение дипломатии к тому, что должно было одушевлять ее всею силою руководящего начала» [11, с. 80].

Разумеется, руководящим началом тут были интересы русского национального государства. Однако им вполне соответствовало и установление во Франции твёрдого национального правительства: «Августейший дед вашего величества, император Николай, как сказывают, говаривал: "Я понимаю республику, по не понимаю лжи конституционных монархий". В самом деле, не лучше ли простое отсутствие монархического начала в стране, его лишившейся или до него недошедшей, нежели его лживое подобие? Для нас монархическое начало истинно и свято лишь в том значении, какое сообщается ему нашею восточною церковью и историческими судьбами России [...]. Вследствие политических причин оба народа нередко сталкивались, но после борьбы противники расходились друзьями, и в народном чувстве ни с той, ни с другой стороны не оставалось озлобления. Дело в том, что у обоих пародов нет соприкасающихся интересов. Им не в чем делиться между собой. Они никогда не въедались друг в друга» [11, с. 72-73].

Антиклерикализм республиканской Франции тоже скорее способствовал сближению двух держав: «Франция есть главная римско-католическая держава, она старшая дочь западной церкви. Ее правительства ставили своим долгом ратовать за интересы папства. Но, как нарочно, Франция находится именно теперь в разгаре борьбы с папством [...]. В настоящее время мы можем быть, по крайней мере, уверены, что Франция не будет на Востоке руководиться клерикальной политикой, чего нельзя было бы с уверенностью сказать в случае монархической реставрации во Франции, при воцарении Орлеанской династии, к тому же породнившейся с королем фантастической Польши» [11, с. 72-73].

Таким образом, пропагандировавшийся Катковым и в итоге заключенный Александром III союз авторитарной России с республиканской Францией был обусловлен самим ходом развития политических культур двух централизованных европейских держав, шедших по пути строительства гражданских наций. Впрочем, и твердой уверенности в этой общности у Каткова, как и у самого Александра III не было. Так, один из агентов «московского громовержца», И.Ф. Цион примерно в это же время сообщал: «Массы убеждены, что в случае войны Россия поспешит Франции на помощь [...]. Если, не дай Бог, Франция потерпит поражение и надежда масс на нашу помощь не сбудется, то теперешний энтузиазм превратится быстро в противоположное чувство. С подвижностью, свойственной французам, они перескочат в другую крайность, бросятся на десятки лет в объятия Германии и, убедившись, что мы им не помогли, они сделаются нашими заклятыми врагами. Я имею претензию знать французов и Францию, как их знают немногие, и я уверяю Вас, что это откровенно высказанное мнение абсолютно верно». Сообщал Цион и о противодействии германских агентов, не забывая намекнуть на необходимость поддержки собственных усилий со стороны русских властей: «Как можете себе представить, Берлин немало работает здесь в враждебном нам смысле и работает, вооруженный более серьезным орудием, чем мы [...]. Они имеют свои входы и выходы во многих газетах и журналах. Десятки салонов работают для них [...]. В случае действительного союза и следа не останется от всей этой пропаганды, - но в противном случае их усилия примирить Францию и Германию могут увенчаться успехом» $[26$, л. 5-10].

Не надеясь пока на заключение формального союза между государствами, Катков и Цион вели деятельность по «установлению дружеских сношений» с французской политической и финансовой элитой. И.В. Лукоянов относит начало этой работы к лету 1886 г. При этом исследователь предполагает, что «финансы являлись, прежде всего, личным предприятием И.Ф. Циона» [9, с. 371]. Политическим сближением занялся генерал Е.В. Богданович, чья поездка во Францию в конце 1886 - начале 1887 гг. стала предметом оживленного интереса французской прессы и, как следствие, громкого скандала в самой России. 17 мая 1887 г. генерал был уволен со службы по личному указанию Александра III. Причиной стали «дошедшие до его величества по министерству внутренних дел сведения о том, что названный генерал во время пребывания в Париже в конце 1886 или в начале 1887 года входил в переговоры с тамошними политическими деятелями с целью практического осуществления появившегося в то время в России нового течения общественной мысли о пользе политического сближения с Францией. Это течение, вполне отвечая предначертаниям Государя, было неугодно Его Величеству в своих тогдашних проявлениях, так как открытая агитация, во главе которой стоял Катков, резко критиковала деятельность нашего министерства иностранных дел и подвергала ожесточенным нападкам дружественное и союзное нам в то время германское правительство» [20, л. 1-1об].

Увольнение Богдановича стало одним из завершающих аккордов той борьбы, которую «московскому гро- 
мовержцу» пришлось выдержать в последний год своей жизни. Как известно, еще в марте 1887 г. над «Московскими ведомостями» нависла угроза цензурного предостережения за антигерманскую передовую статью, в которой содержался призыв к союзу с Францией и разглашались детали Тройственного союза [17]. Александр III воспринял публикацию как покушение на его прерогативу руководить внешней политикой страны. От Е.М. Феоктистова и К.П. Победоносцева потребовались значительные усилия по обелению в глазах государя имени публициста, а обер-прокурору даже удалось организовать ему 20 марта царскую аудиенцию, закончившуюся благополучно: «Государь два раза пожал руку Каткова и обнадежил его своим расположением. От всей этой прискорбной истории с "Московскими ведомостями" не осталось и следа». Феоктистов также сообщал: «Суждения Каткова о международных наших отношениях были ему (Александру III - А.К.) видимо симпатичны. Гирса он защищал. Катков заметил, что недоверие публики к Гирсу объясняется нерусским его происхождением и тем, что, вращавшись всю жизнь в дипломатических сферах, он не знает России и едва ли мог составить он вполне ясное и отчетливое понятие о том, что такое русские интересы на Востоке. “И мне известно, сказал государь, что его считают иностранцем, но отчасти это даже хорошо: он сам тяготится такими упреками и ужас как старается он выставить себя русским, все его помыслы направлены к этому!.. Для меня он в настоящую минуту как нельзя более пригоден. Весьма может быть, что нам не обойтись без войны; это будет война жестокая и продолжительная, но именно в виду этого я не сделаю ни одного решительного шага до тех пор, пока не окончу самые необходимые приготовления. Поневоле надо медлить, стараться выиграть время; не надо зарываться и Гирс не зарвется; среди теперешних обстоятельств его осторожность - драгоценное качество"» [25, л. 12 об. - 13]. Помимо этого, Каткову было настоятельно рекомендовано наладить отношения с министерством иностранных дел - что, впрочем, не вызвало энтузиазма у самого Гирса: «Государь выразил Каткову настоятельное желание, чтобы тот посетил Гирса. Катков исполнил это на другой же день, не застал дома министра иностранных дел и оставил ему свою карточку. Теперь от Гирса зависит уведомить его, желает ли он с ним видеться или нет. Катков свое дело сделал» $[25$, л. 13-14].

Однако уже в мае разразился новый скандал: против Каткова было выдвинуто обвинение в отправке президенту французской Палаты депутатов Ш. Флоке письма с обещанием поддержки русского правительства. Сообщение об этом (исходившее из русского посольства в Париже) вызвало гнев государя, заметившего: «Катков, может быть, сам и не виноват, а это всё группирующиеся около него подлецы и мерзавцы - Богданович, Татищев и Цион» [23, с. 305-307]. По свидетельству Феоктистова, Александр III отметил также, что «Татищевы, Богданови- чи, Ционы, - все это мерзкие интриганы, которыми руководит Н.П. Игнатьев, чтобы сесть на место Гирса» [25, л. 15]. К числу этих интриганов можно причислить и еще одного знаменитого генерала - В.В. Комарова, о котором уже в 1888 г. А.В. Богданович записала в дневнике: «Он стоит за графа Игнатьева, есть у этого болтуна тоже своя партия» [1, л. 55]. Судя по дневнику А.А. Киреева за 1887 г., в катковском окружении в это время действительно обсуждалась идея вернуть министерский портфель Н.П. Игнатьеву - и, разумеется, речь шла не о министерстве внутренних дел $[6$, л. 6].

Именно после истории с письмом Флоке были отправлены в отставку Е.В. Богданович, а также П.А. Сабуров, заподозренный в передаче сведений Каткову. В невиновности Каткова был убежден также и Е.М. Феоктистов: «Если бы Катков имел безумие вмешиваться в вопросы о формировании французского министерства и делать заявления от имени нашего правительства (!!), то, конечно, надо было бы освидетельствовать состояние его умственных способностей. [...] Никогда и никому, - ни самому Флоке, ни к постороннему лицу о Флоке, - не писал он ни единого слова. Только безмозглый мальчишка мог бы выкинуть подобную штуку. Теперь Флоке известен тем, что он президент палаты депутатов, а в прежнее время он поставил себя в известность дерзкою выходкой против нашего покойного Государя. Почему же Катков мог желать министерства Флоке? Что тут было выгодного для России? Нелепость так очевидна, что и опровергать ее не стоит. Катков был вне себя от изумления, когда я сообщил ему о клевете, органом коей сделался наш посол; он понял, что враги наносят ему удар, чем ни попало, не разбирая средств» $[25$, л. 15].

Упомянутый Феоктистовым русский посол в Париже А.П. Моренгейм своё участие в этой истории отрицал сложно сказать, насколько искренне. Н.В. Щербань в письме Каткову передавал следующее: «Кстати, я сообщил барону ходячие по Парижу толки (еще не попавшие в печать) о клевете, взводимой на Вас (письмо, будто бы писанное Вами Флоке). Эта выдумка очень огорчила Артура Павловича, который питает к Вам (и еще к покойному И.С. Аксакову) большую приязнь и уважение. Естественно было пораскинуть умом, кто мог пустить клевету? Прикидывали, прикидывали - ни к чему не пришли: да и имена одиозны в таком темном деле. А по моему личному мнению, если это пущено не из Берлина, то пустили в ход сами безмозглые французы, Клемансо с Буланже и Ко, в момент кризиса, для того, чтобы подействовать на Греве кулуарным палатным слухом, говорящим: "вот, видите, с этой стороны не бойтесь, и назначайте Флоке". Эти люди так пусты, и так бесцеремонны в шарлатанских приемах воздействия, что от них станется подобный маневр. А там и пошло, и дошло - кажется, я не ошибаюсь» [4, с. 278-279]. А.А. Киреев считал это происшествие «делом по преимуществу Зиновьева, врага 
Каткова и катковских идей» [6, л. 6].

Впрочем, окончательно Александр III убедился в невиновности Каткова только в 1888 г., благодаря документам, переданным И.Ф. Ционом через К.П. Победоносцева. В них соратник уже покойного «московского громовержца» указывал на непосредственных создателей подделки - русско-французского журналиста Сивиньи и сотрудника посольства Г.К. Катакази [4, с. 361-383]. Е.В. Перевалова полагает, что за спиной последнего стояли «многие представители высшей бюрократии», в частности, А.А. Половцов [19, с. 243-244]. Всё это сыграло свою роль и в истории с парижской поездкой Е.В. Богдановича. И.В. Лукоянов приводит достаточно серьезные аргументы в пользу непричастности М.Н. Каткова к его поездке во Францию [10, с. 237]. Однако, на наш взгляд, об обратном свидетельствуют многочисленные упреки в адрес недавно умершего публициста, которыми пестрит дневник А.В. Богданович за 1888 г. и, в частности, сделанная 20 января запись «умри он раньше, всего этого (т.е. отставки Е.В. Богдановича - А.К.) бы не было» [1, л. 20 об]. По всей вероятности, небеспочвенным было предположение Е.М. Феоктистова: «Вообще, трудно было разобраться в этой истории; мне кажется даже, что и Катков очень хорошо знал, что Богданович ездил в Париж вовсе не в качестве только любознательного путешественника, но, во всяком случае, Богдановича давно уже следовало выгнать из службы за мошенничество, а отнюдь не за какую-то политическую пропаганду» [24, с. 255]. Но, разумеется, в парижской деятельности Богдановича не могло не быть и элемента хлестаковщины - под вопросом лишь доля последней в происходившем.

В этой ситуации Михаил Никифорович был вынужден дистанцироваться от опального генерала - однако определенные действия в его поддержку всё же предпринял. Так, незадолго перед смертью он писал Победоносцеву: «Я протестую против толков о какой-то моей солидар- ности и интимности с ним, но не потому, чтобы считал его в политическом отношении неблагонамеренным. Но я и не имею с ним ничего общего ни в умственном, ни в нравственном складе. Мы люди совершенно разных миров. И сотрудником моим он никогда не был, и только из снисхождения к нему печатались его телеграммы о нем самом. Он изо всего делал себе рекламу и этим более всего вредил себе в мнении серьезных людей. Но я считаю его совершенно не способным к чему-либо, не согласному с долгом верноподданного. Богданович повредил себе своими рекламами. Ему придали серьезное политическое значение, какого он ни в коем случае не имел и иметь не может» [4, с. 276-277].

В итоге, как мы знаем, восторжествовала линия Каткова: союз с Францией был заключен. Однако его цена для «русского направления» оказалось слишком высока: лишившись идейного вождя, оно одновременно лишилось и доверия государя, и внутреннего единства - и, как следствие, влияния на государственные дела. Характерно, что именно с этим периодом некоторые современники связывали упущенную возможность либерализации внутренней политики. К.Ф. Головин отмечал: «в половине 80-х гг., когда правительство было в зените своей популярности, а среди общества стояла тишь да благодать, был едва ли не лучший момент прочно заинтересовать культурные классы в ходе официального механизма [...]. За самое скромное допущение выборного элемента в центральные учреждения были бы тогда благодарны» [3, с. 99]. Ю.С. Карцов считал, что именно тогда произошел «разрыв Царя с националистами»: «вторая половина царствования представляет господство бюрократии в чистом виде sans phrases. Откровенно, со спокойною совестью, задачи национально-исторические кладутся под сукно» [5, с. 390]. Разумеется, долю ответственности за это несет и сам Катков, чья логика «бюрократического национализма» не оставляла никаких иных субъектов национального строительства, кроме «правительства».

\section{ЛИТЕРАТУРА}

1. Богданович А.В. Дневник. Март-июнь 1888 г. // РГИА. Ф. 1620. Оп. 1. Д. 239.

2. Галахов А.Д. Воспоминания о журнальном сотрудничестве М.Н. Каткова в 1839 и 1840 годах // Исторический вестник. 1888. Т. 31. № 1. С. $97-112$.

3. Головин К.Ф. Мои воспоминания за 35 лет (1859-1894). СПб.: Т-во М.0. Вольф, [б. г.]. (2-е изд.). 684 с.

4. К.П. Победоносцев и его корреспонденты. Т. 2. Минск: Харвест, 2003. 672 с.

5. Карцов Ю.С. Семь лет на Ближнем Востоке. 1879-1886. Воспоминания политические и личные. СПб.: Экон. типо-лит., 1906. 393 с.

6. Киреев А.А. Дневник. 1887-1894// НИОР РГБ. Ф. 126. К. 11.

7. К Котов А.Э. «Царский путь» Михаила Каткова: Идеология бюрократического национализма в политической публицистике 1860-1890-х годов / науч. ред. С.К. Лебедев. СПб.: Владимир Даль, 2016. 487 с.

8. Леонтьев К.Н. Избранные письма. СПб.: Пушкинский фонд, 1993. 642 с.

9. Лукоянов И.В. А.П. Моренгейм «не знает, чьим инструкциям следовать, МИД или генерала Богдановича»: как проходило русско-французское сближение конца 1880-х гг. // Санкт-Петербург - Франция. Наука, культура, политика. СПб.: Европейский Дом, 2010. С. 364-385.

10. Лукоянов И.В. М.Н. Катков и внешняя политика Российской империи в царствование Александра III (1880-е годы) // Тетради по консерватизму. 2018. №3. C. 234-244. 
11. М.Н. Катков и Александр III в 1886-1887 гг. // Красный архив. 1933. Т. 3. С. 58-85.

12. Московские Ведомости. 1864. № 174.8 августа.

13. Московские ведомости. 1864. № 252. 17 ноября.

14. Московские ведомости. 1870. № 194.9 сентября.

15. Московские ведомости. 1870. № 270.14 декабря.

16. Московские ведомости. 1886. № 190.3 сентября.

17. Московские ведомости. 1887. № 66.8 марта.

18. Московские ведомости. 1887. № 82.23 марта.

19. Перевалова Е.В. «Русская Тітеs»: газета «Московские ведомости» под редакцией М.Н. Каткова. М.: Издательство Московского Политеха, 2020. С. 243-244.

20. Плеве В.К. - Сипягину Д. С. 1900-1902 // РГИА. Ф. 1620. Оп. 1. Ед. хр. 3.

21. Половцов А.А. Дневник государственного секретаря: в 2 т. Т. ІІ. 1887-1892. М.: Центрполиграф, 2005. 639 с.

22. Пророки византизма: переписка К.Н. Леонтьева и Т.И. Филиппова (1875-1891). СПб.: Пушкинский дом, 2012. 728 с.

23. Суворин А.С. Дневник. М.: Независимая газета, 2000. 670 c.

24. Феоктистов Е.М. За кулисами политики и литературы. М.: Новости, 1991. 464 с.

25. Феоктистов Е.М. Дневник // ИРЛИ. Ф. 318. Ед. хр. 9120.

26. Цион И.Ф. - М.Н. Каткову // ГАРФ. Ф. 1718. Оп. 1. Ед. хр. 11.

(с Котов Александр Эдуардович (a.kotov@spbu.ru).

Журнал «Современная наука: актуальные проблемы теории и практики»

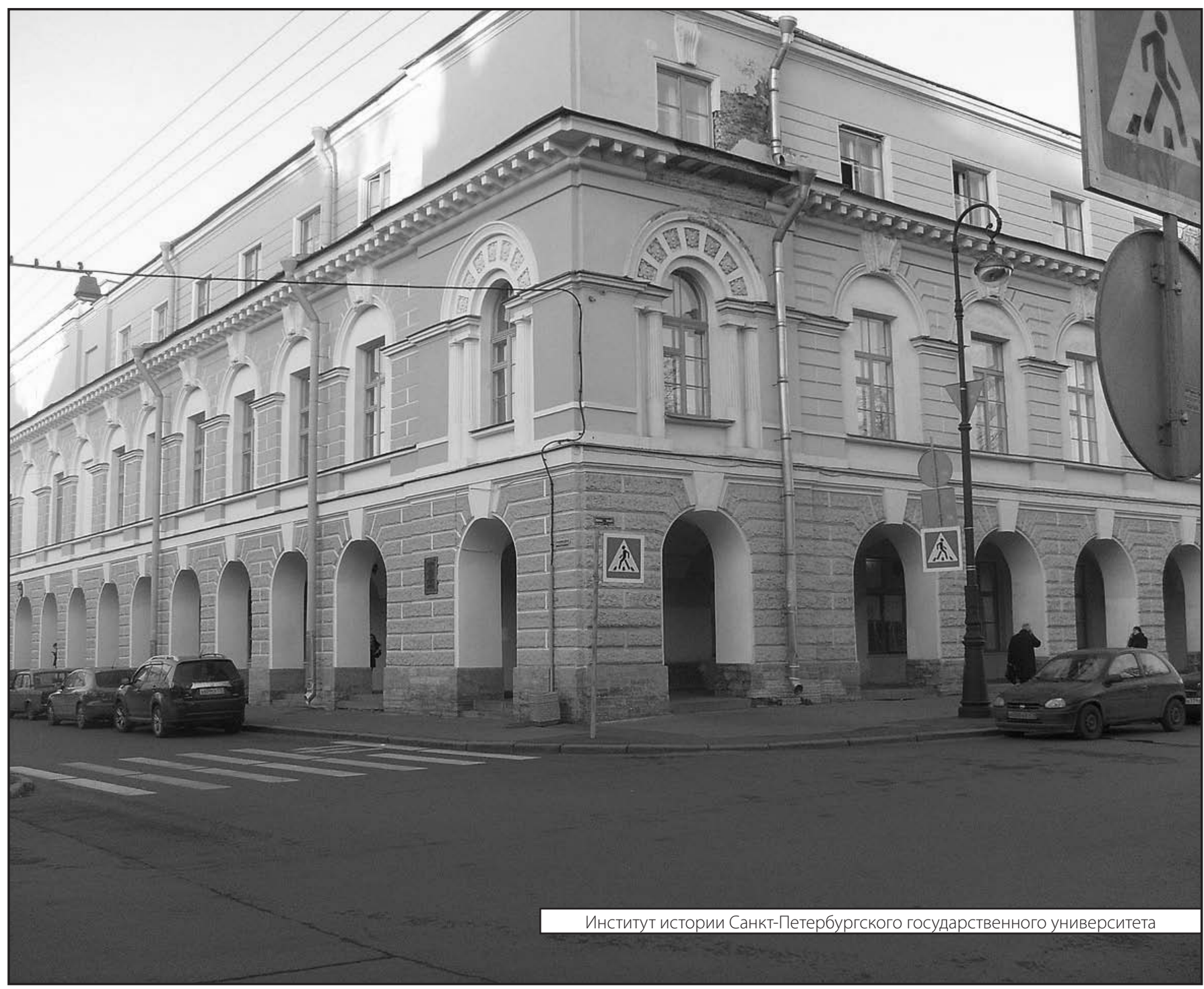

